Article

\title{
Revisiting the Right to the City, Rethinking Urban Environmentalism: From Lifeworld Environmentalism to Planetary Environmentalism
}

\author{
Margaret Haderer \\ Institute for Social Change and Sustainability (IGN), Department of Socioeconomics, WU Vienna, \\ Welthandelsplatz 2, 1020 Vienna, Austria; margaret.haderer@wu.ac.at
}

Received: 26 November 2019; Accepted: 4 February 2020; Published: 11 February 2020

\begin{abstract}
In the environmental politics literature, cities are commonly framed as key sites for a shift towards greater sustainability and urban grassroots initiatives, such as food co-ops, urban gardening initiatives, repair cafés, and libraries of things, are commonly portrayed as such a shift's key drivers. This paper develops a critical perspective on both common portrayals. It does so by drawing on critical urban theory, especially Lefebvre's Right to the City. First, inspired by Lefebvre's critique of city-centrism, the paper argues that the scope and limits of urban environmentalism hinge not only on the goals pursued but also on how the urban is framed. Urban environmentalism may mean mere lifeworld environmentalism: the greening of cities as if there were (relatively) bounded sites. Yet urban environmentalism may also mean planetary environmentalism: the mapping, problematization, and transformation of unsustainable urbanization processes that underpin given sites and lifeworlds, but also operate at beyond the latter-at a societal and planetary scale. Second, inspired by Lefebvre's reformulation of right claims as a transformative political tool, this paper takes issue with environmental practices and discourses that present society's niches, cracks, and margins as a key fermenting ground for radical environmental change. Since not only institutional but also bottom-up pursuits of more sustainable nature-society relations often remain stuck in mere lifeworld reform, this paper foregrounds heterodox right claims as an underexplored modus operandi in active pursuits of and discourses on radical environmental change. Heterodox right claims mean the active appropriation of dominant political languages, such as the language of right, while seeking to change the latter's grammar. What this may mean in the realm of environmental politics, will be spelled out at hand of the example of claims to a right to public transport.
\end{abstract}

Keywords: urban environmental politics; urban theory; the Right to the City; lifeworld environmentalism; planetary environmentalism; grassroots practices; heterodox right claims; the right to public transport

\section{Introduction}

In recent years, especially cities in the Global North seem to have turned into vibrant sites for acting on socio-ecological challenges, such as climate change, resource exhaustion, biodiversity loss, and socio-ecological injustices. Given ongoing urbanization, the common narrative goes, coming to terms with socio-ecological challenges is an increasing urban challenge. Cities are being conceived of and conceive of themselves as key drivers of a shift towards greater sustainability (UN-Habitat-United Nations Human Settlements Programme 2011; WBGU 2016; Global Covenant of Mayors for Climate and Energy 2019). Urban environmentalism encompasses institutionalized politics and with it, the passing of policies, laws, regulations, the establishment of networks and co-operation, and urban planning. It also encompasses grassroots environmental interventions that focus, among others, on the making 
and re-making of urban everyday life and with it, notions of citizenship - the focus of this Special Issue. Frustrated with the little headway being made towards more sustainable nature-society relations by established political institutions, more and more people seem to take action on socio-ecological challenges into their own hands. Instead of waiting for a "great socio-ecological transformation" to be launched "from above", an increasing number of urban dwellers and citizens grow and distribute food locally, join repair cafés, take part in clothing swaps, borrow tools from libraries of things, build and live in eco-housing, and commit to more sustainable forms of mobility. Although none of these bottom-up practices are per definitionem urban practices in the sense that they would, in any way, be bound to emerge in cities, it is a matter of fact that they do commonly emerge in cities. As a result, they nourish the common perspective that a socio-ecological transformation heavily hinges on the transformative power of cities and their environmentally engaged citizens (on this perspective, see also Brenner and Schmid 2014; Angelo and Wachsmuth 2015).

In this article, which is decidedly conceptual in nature ${ }^{1}$, I offer a critical perspective on the "urban turn" in environmental sociology and politics by drawing on urban theory, more precisely, Henri Lefebvre's theory of the Right to the City. The purpose of doing so is twofold. First, Lefebvre (and urban theory since Lefebvre, see below) take issue with the common practice to reduce the meaning of the urban to cities, a reduction that often also shapes environmental practices and discourses. By revisiting Henri Lefebvre (Lefebvre 1996a, 2003a, 2003b) and critical urban theory more generally (Merrifield 2013; Brenner and Schmid 2015, 2011; Wachsmuth 2014), I introduce an analytical distinction with view to conceptions and framings of the urban and present it as potentially relevant for assessing the scope and limits of urban environmentalism. The distinction is between the urban as a site (e.g., the city) and the urban as a process (with societal and planetary implications). If the urban is understood and framed primarily as a site, urban environmentalism may embody, first and foremost, lifeworld environmentalism, the creation of cleaner, greener, more desirable, and more pleasant local environs, such as cities. Yet if the urban is, as Lefebvre suggests, understood not primarily as a site, but as a process with far-reaching economic, socio-metabolic, ecological, political, and morphological implications, urban environmentalism may also mean planetary environmentalism, the politicization and transformation of urban processes that become manifest in local environs and lifeworlds, while (also) operating at a societal and planetary scale. Against this backdrop, the first argument this paper presents is that the transformative scope of urban environmentalism depends not only on the nature of the intervention pursued and the latter's underpinning normative goals (e.g., green growth versus post-growth) but also on how the urban is conceived and framed. In light of (potentially) radically different conceptions of the urban, greater reflexivity on (the often hidden) epistemologies and framings of the urban in environmental practices and discourses may be warranted.

Second, revisiting Lefebvre's theory of the Right to the City also invites critical reflection on the common assumption that radical (as opposed to merely reformatory) societal change hinges on the

1 Conceptual, in this paper, means that this article is not driven by empirical research. The "material" this paper engages with are phenomena (e.g., the "urban turn" in environmental sociology and politics), academic discourses on these phenomena (e.g., discourses in environmental sociology and politics), and existing conceptual tools (e.g., the distinction between the urban as a site and the urban as a process). Its "methodology" is the engagement with existing academic discourses against the backdrop of the "urban turn" in environmental politics by reading, writing, re-considering, and re-interpreting existing texts. Its "findings" are the identification of blind spots within existing debates; shifts in ways of seeing (interpretations); and the introduction of new analytical tools (lifeworld environmentalism, planetary environmentalism) and underexplored, existing concepts (heterodox rights). Fully aware of the prominence of empirical approaches (be they qualitative or quantitative) in the social sciences, including this journal, this paper decidedly operates within the non-empiricist epistemologies that are also part of the social sciences and embodied by, among others, political theory, urban theory, and social theory. Terms that are commonly used in empirical papers are uncommon, such as "methodology", "data material", "findings". The reason for the letter is not neglect, but different, non-empiricist epistemic traditions. With view to the different epistemological traditions in conceptual approaches, I position myself closes to critical theory, without, however, assigning too quickly to a critique of capitalism, as some strands of critical urban theory do, e.g., urban political ecology (Wachsmuth and Angelo 2018; Ernstson and Swyngedouw 2019). The underpinning normative horizon that shapes this article is the conviction that in light of the socio-ecological challenges we are facing, radical (and not merely reformatory) socio-ecological change is key. 
formation of collective subjects and social movements that operate at a (certain or even deliberate) distance from dominant political languages and institutions. Lefebvre presents an alternative approach to radical societal change: the (creative and cunning) appropriation of dominant political languages and institutions, such as the language of right and the institution of law, while changing the latter's grammar and underlying "contracts of citizenship (Lefebvre 2003a)". The political theorist Margaret Kohn refers to claims to the Right to the City as "heterodox rights claims" (Kohn 2016, 176ff.). Against this backdrop, the second thrust of this article is to present heterodox rights claims as a critical perspective on an assumption that can also be commonly found in contemporary urban, bottom-up environmentalism (food co-ops, repair cafés, libraries of things, urban gardens) and-the focus on this paper-academic discourses on them (Paech 2011; Meyer 2015; WBGU 2016; Muraca 2017; MacGregor 2019; Schlosberg and Craven 2019; Fladvad 2019 in this Special Issue). Although different in their respective analyses and framings of the urban turn in bottom-up environmentalism, there seems to be a high degree of readiness among environmental scholars to ascribe transformative thrust to bottom-up initiatives. They are commonly presented as promising "prefigurations" of more sustainable nature-society (Muraca 2017; Schlosberg 2019). Operating within society's "cracks" (MacGregor 2019) and "acting otherwise" (Fladvad 2019) is commonly portrayed as a promising pathway towards and political strategy for transforming the unsustainable status quo. Yet, one may argue, at times when the socio-ecological crises we are facing are rapidly worsening rather than improving (Steffen et al. 2015; Fritz and Koch 2016; Bendell 2018), operating at a distance from dominant political languages may not be (radical) enough. Without doubting that institutional approaches to environmental change do indeed often amount to mere lifeworld environmentalism, the paper underlines the importance to (also) recognize that and make sense of why bottom-up environmental interventions that pursue more than mere lifeworld reform (e.g., planetary environmentalism) often remain stuck in the niche. The reasons for the latter, to be sure, are manifold and exceed the scope of this paper, but the political strategy may be one of them. Thus, this paper presents heterodox right claims as an invite to reflect more critically on existing doxa in scholarly engagements with bottom-up environmentalism, but also as an outlook on other political strategies for pursuits of ecological citizenship and radical socio-ecological change, a strategy that may be worth exploring and paying attention to, also intellectually.

The structure of this paper, which seeks to bring writings that engage with the "urban turn" in environmental sociology and politics into conversation with urban theory, is as follows: in the next Section 2, I present Lefebvre's take on the urban. Based on his differentiation between conceiving the urban as a planetary process rather than a site, this section introduces an analytic distinction between urban environmental interventions that amount to lifeworld environmentalism (a city-centric environmentalism) and urban environmental interventions that embody planetary environmentalism (interventions that map, problematize, and seek to transform urbanization processes that shape localities, but that operative beyond the latter). In Section 3, I agree with the diagnoses, that has become common in environmental politics, that so far institutional approaches to socio-ecological change have predominantly ushered in, what I call lifeworld environmentalism while leaving planetary unsustainabilities largely intact. Yet, it also shows that many active pursuits of planetary environmentalism, pursuits that are indeed common in bottom-up initiatives, also remain often "stuck in the niche" and that, among many other things, a political strategy may have to do with this "stuckness". Critical of the idea that transformative (as opposed to merely reformatory) environmental politics hinges on a (certain) distance from established political languages and institutions, Section 4 introduces a political strategy that is meant as a political tool for radical change, but is less critical of engaging with established political languages, such as the language of right and institutions of law: the strategy of heterodox right claims, which underpins Lefebvre's Right to the City-theory. What heterodox right claims may mean in the realm of environmental politics will be exemplified by a right to public transport. Section 4 is followed by the conclusion in Section 5 . 


\section{Rethinking the Urban, Distinguishing between Lifeworld Environmentalism and Planetary Environmentalism}

There is a narrative that is frequently found in discourses on the urban in the environmental sociology and politics literature: due to ongoing urbanization, the shift of societies towards greater sustainability heavily hinges on the greening of cities (see, among others, UN-Division for Sustainable Development Goals 2019; Bulkeley et al. 2010; UN-Habitat-United Nations Human Settlements Programme 2011; Bulkeley et al. 2014; WBGU 2016). For the first time in human history, the common narrative continues, more people live in urban rather than rural areas. Relatedly, most of the worldwide energy consumption is urban consumption and most of the worldwide carbon emissions are urban emissions (UN-Division for Sustainable Development Goals 2019). Against the backdrop of this specific framing of urbanization, it appears to be self-evident that a shift towards more sustainable nature-society relations depends, to a large extent, on making cities and urban environs more sustainable. It is also commonly emphasized that such a shift hinges not only on policymakers, architects, and planners who are expected to govern, build, and plan more sustainable urban environs but also on the bottom-up engagement of civil society (see also the framing of this Special Issue).

In his writings on cities (Lefebvre 1991, 1996b, 2003b), Lefebvre provides a different, more nuanced interpretation of urbanization and the challenges that come with it. From a Lefebvrian perspective, urbanization cannot be reduced to the demographic and morphological growth of urban agglomerations. Nor did he conceive of the urban as a specific site or administrative unit, the city. According to Lefebvre, urbanization is best understood as a societal and even planetary process with far-reaching implications. Driven by his study of post-WWII changes to the French countryside and his engagement with the production of space, already in the 1970s, Lefebvre noted a double crisis: "the crisis of the traditional city" and "the crisis of the traditional countryside". The traditional city, a reference by which Lefebvre always implied (but never explicitly acknowledged) a European vision of the city, was in crisis because it increasingly lost its contained form, (relative) political autonomy, and its cultural distinctiveness. Simultaneously, Lefebvre related the "de-ruralization" of the countryside to the industrialization of agriculture, the devaluation of craftsmanship, and the loss of importance of small, local centers (Lefebvre 1996a, 2003b). Although cities still commonly celebrate their "city-ness" and villages their "rural-ness", such celebrations often have more to do with nostalgia for a time long past or with profit-driven place branding in order to attract tourists-with "enrichissement" as Boltanski and Esquerre frame it (Boltanski and Esquerre 2020) — than with the actual existence of distinctively urban or distinctively rural spaces. The dissolution of the traditional urban-rural divide, a binary that is nonetheless still commonly shaping academic disciplines, such as urban studies, urban sociology, planning, and political science, has ushered in the spread of what Lefebvre calls an "urban fabric". The latter

“... does not narrowly define the built world of cities but all [emphasis added] manifestations of the dominance of the city over the country. In this sense, a vacation home, a highway, a supermarket in the countryside are all part of the urban fabric. Of varying density, thickness, and activity, the only regions untouched by it are those that are stagnant or dying, those that are given over to 'nature'." (Lefebvre 2003b)

Thus, instead of focusing on cities as if they were distinct sites, which is just one variant of conceiving of the urban (Brenner 2017), Lefebvre suggests to place more attention on the specific societal and planetary processes that go along with urbanization in late modernity and the related unfolding of the urban fabric (Lefebvre 2003b). The latter implies as Lefebvre put it, a dual process: the implosion of the traditional city and the explosion of urban processes that remake local environs, reach far into the countryside and hinterlands, and across the globe (Lefebvre 2003b). Understanding the urban as a manifestation of planetary processes comes with economic, socio-metabolic, morphological, socio-cultural, and socio-ecological implications. From an economic perspective, late modern urbanization (in contrast to previous forms of urbanization), constitutes, as Lefebvre puts it, a new, 
"neo-capitalist", post-industrial mode of production, to which "steam" is less important than the "conquest of space" (Lefebvre 2003b, 2009): highly mobile capital whose investors are less interested in making profit with producing and selling goods than with the speculation with urban and agricultural land at a global scale. Urbanization understood as a planetary mode of production implies socio-metabolic processes that subject not only urban hinterlands and the countryside to the production and reproduction of the urban fabric's nodal points, but also distant parts of the world. This dominance of the urban over regional or global peripheries is embodied, for instance, by logistic centers on green fields no less than by flagship smart city developments that hinge on the mining of rare earth in remote areas in the Global South. Morphologically, suburbanization is an expression of the urban as a process that calls into question the traditional binary between city and country, no less than the evacuation of the countryside in some parts of the globe and the emergence of megalopolis in other parts. Culturally, urbanization implies forms of consumption and lifestyles that cut across traditional urban-rural divides and geographical boundaries. The things one can consume in a suburban box store are often no different from the things one can purchase in an inner-city mall regardless of where the mall is located, close to home or in a different country. Socio-ecologically, it entails what McKibben later called "the end of nature" (McKibben 2006). Although even today, we may still think of an adventure to Argentine's Tierra del Fuego or a swim in a remote Alpine lake as an escape from urban life, from a Lefebvrian perspective, both are part and parcel of the latter, given an infrastructure (airports, highways, the tourist industry) that not only connects urban agglomerations to wilderness, but that also subjects the latter to consumptive, urban lifestyles (Lefebvre 1991, 2003b, 2009; Schmid 2005; Brenner and Schmid 2011; Brenner 2017). One key insight from Lefebvre's analyses of the urban (analyses that have been taken up and developed further in various strands of critical urban theory (Brenner and Schmid 2014; Merrifield 2013; Brenner and Schmid 2015; Angelo and Wachsmuth 2015; Angelo 2017; Brenner 2017; Ernstson and Swyngedouw 2019), is an analytic insight: the scope and limits of urban environmentalism hinge not only on how one defines the environmental goal (e.g., sustainability) and the pathways towards it, but also on how one understands and frames the urban. If the latter is predominantly conceived of as a specific site or administrative unit (the city), the scope and limit of urban environmentalism is likely to be limited to what Daniel Hausknost refers to as "lifeworld sustainability": the transformation of local environs into cleaner, more pleasant, socially and materially secure, and desirable environs. Lifeworld sustainability, as Hausknost explains, typically includes concerns for environmental quality (such as clean air and water, safe and affordable food, the absence of toxic substances in the immediate lifeworld, and green space for recreational purposes); material abundance for and the well-being of local citizens (embodied by monetary income, opportunities for consumption and individual mobility, social security); and realms for cultural expression and activity (emphasis added; Hausknost 2019, pp. 8-9). Although pleasant for all those who come to enjoy "lifeworld sustainability", from a planetary perspective, the greening of local environs, including urban environs, has so far been spectacularly unsustainable. Resource consumption and C02-emissions have risen rather than fallen in and because of countries in the Global North-despite three decades of sustainability discourses and interventions, including urban interventions (Steffen et al. 2015; Fritz and Koch 2016; Bendell 2018).

To be sure, city-centric urban environmentalism, which I refer to as lifeworld environmentalism, has been, in many ways, successful. In contrast to the nineteenth-century, the environmental and social costs of urbanized life are no longer in the face of local urban dwellers and citizens, but out of sight in most contemporary cities in the Global North. A common conditio sine qua non for the creation of cleaner, greener, more pleasant local environs has been the externalization of the social and environmental costs of Western lifestyles to other parts of the world (e.g., the Global South), non-human beings, and into the distant or not so distant future (Brand and Wissen 2018; Wachsmuth and Angelo 2018; Lessenich 2019). Yet if the urban in urban environmental interventions is not reduced to "city-ness" (for a critique of this reduction, see also Angelo and Wachsmuth 2015), but conceived of and framed as a product of and producer of unsustainable societal and planetary processes, then 
pursuing urban environmentalism may also mean more than lifeworld environmentalism: namely, the mapping, problematizing, and-ideally-reconfiguring of urban(ized) life and (some of its) economic, socio-metabolic, socio-ecological, and socio-cultural implications that underpin, but clearly also operate beyond the boundaries of any given city. I call this process-oriented urban environmentalism planetary environmentalism.

\section{Urban Environmentalism and Its Drivers: On Cities and Citizens and Their (Ascribed) Transformative Thrust}

Urban lifeworld environmentalism-understood as the greening of cities (as if they were relatively bounded sites) — tends to be the key concern of institutionalized politics: e.g., the politics of the (local) state. Given the dependency of local governments on local electorates, environmental politics that are more concerned with lifeworld improvements than changes to planetary processes are, from an environmental perspective, clearly insufficient. Yet city-driven lifeworld environmentalism may not come as a surprise and even make sense against the backdrop of the political logic of and constraints within liberal democratic institutions, such as the logic and constraint of political legitimacy. In short, political logic is not forcibly compatible with environmental logic, such as sustainability at a translocal, planetary scale. In light of climate change, for instance, acting decisively, conjointly, and trans-locally on a transformation from "carbon democracies" (Mitchell 2013) towards low or post-carbon democracies is clearly necessary and widely perceived as necessary. Yet politically it is difficult to realize, since the legitimacy of liberal capitalist institutions, including the local state, is (still) deeply dependent on "dense energy"-based economic growth, which fuels not only the market economy but also (local and national) social security systems (Hausknost 2019). To avoid political legitimacy crises, institutional responses to socio-ecological challenges, including the responses of cities, have so far most often meant investing in "green growth". From an environmental perspective, green growth is, by now, known to be insufficient (Barry 2003; Baker 2007; Brand 2010). Yet it is also known to be easier "to sell politically" than, for instance, the end of economic growth.

Thus, for a few years, cities have, among others, been seeking to become "smart" by investing in energy-efficient technologies and infrastructures (Hajer and Dassen 2014). Cities in the Global North have also commonly ascribed to the Local Agenda 21 and, relatedly, the attempt to increase environmental awareness among citizens and urban dwellers by encouraging them to participate in local, socio-ecological projects geared towards increasing sustainability on the ground. A well-known slogan of Agenda 21-initiatives is "act locally, think globally" (for critical engagement, see Lawhon and Patel 2013). Neither of these urban, local state interventions seems to really touch on unsustainable societal and planetary processes. In fact, they may even sustain them (Hausknost 2019). Acting locally and thinking globally is an unbinding, ethical appeal to citizens, who may or may not feel addressed. Although technological innovations that focus on greater efficiency do make for (the experience of) greener lifeworlds, it is a well-known fact that resource-savings from increases in energy efficiency are commonly set off by increases in consumption-the so-called "rebound effect".

Given the limits of (many of the current) institutional approaches to environmental change, the environmental sociology and politics literature often portrays urban hands-on, grassroots environmental interventions as a "sign of hope" for transformative socio-ecological change and/or as the more promising alternative to top-down approaches (Paech 2011; Stolle and Micheletti 2015; Meyer 2015; Soper 2016; Muraca 2017; Schneidewind 2018; Brand and Wissen 2018; Schlosberg and Craven 2019; Fladvad 2019). Certainly, mapping, problematizing, and politicizing unsustainable societal and planetary processes are quite common in urban farming initiatives, food co-ops, repair cafés, eco-housing projects, and similar hands-on, bottom-up initiatives. Concerns for, endorsements of, and active pursuits of more than mere lifeworld reform, are concerns, endorsements, and pursuits one is more likely to find in food co-ops than supermarkets; in local, bottom-up farming initiatives than in associations of conventional farmers; and in initiatives that emphasize repairing and sharing than among people who spend their leisure in shopping malls. Yet against the backdrop of a continued 
worsening of socio-ecological crises, it may nonetheless be critically remarked, that in the Global North (urban) bottom-up initiatives seem to primarily expand existing repertoires of consuming, living, and getting around (mobility) rather than chip away at unsustainable dominant ones. In light of the current dominance of "sustained unsustainability" in the Global North (Blühdorn et al. 2019), not only institutional approaches seem to be "stuck in" lifeworld reform, but also bottom-up initiatives ${ }^{2}$.

The reasons for the latter, to be sure, are manifold and, in many respects, beyond the sphere of influence of any given initiative and even (translocal) network of initiatives: power relations that are unfavorable for pursuits of planetary environmentalism; structural and institutional barriers to a radical shift towards more sustainable nature-society relations (such as the growth paradigm, the fear of a political legitimacy crisis; still deeply engrained conceptions of the good life as one based on consumerism; value pluralism and, relatedly, competing rationalities and normative horizons. To be clear, the diagnoses of "stuck-ness in lifeworld reform" is not meant as a criticism of grassroots environmentalism in general. I am fully aware of and recognize the enormous efforts and commitment that goes into building alternatives to dominant forms of consumption, production, living, and mobility ${ }^{3}$. I also recognize that transformation comes in many different shades. What I do, however, criticize is the readiness with which some scholars in environmental sociology and politics ascribe a transformative thrust to bottom-up environmental initiatives; present it as key to and/or harbinger of more sustainable nature-society relations (Paech 2011; Stolle and Micheletti 2015; Meyer 2015; Soper 2016; Muraca 2017; Schneidewind 2018; Brand and Wissen 2018; Schlosberg and Craven 2019; Fladvad 2019). Against the backdrop of the continued worsening of socio-ecological challenges and heightened awareness for the need of translocal, decisive, and conjoint efforts, the ascription does not seem to hold or needs, at least, further explaining. Moreover, I take issue with the readiness with which some scholars, as well as environmental activists, present operating at a deliberate distance from dominant political languages and institutions, as a sign of or even precondition for radical (as opposed to merely reformatory) environmental quests and interventions (Muraca 2017; Fladvad 2019; MacGregor 2019; Pellizzoni 2020).

In his Right to the City, Lefebvre, someone who was clearly committed to radical societal change (albeit not from an environmental but from a socialist perspective), takes issue with the "doxa" on the left that radical politics hinge on a certain distance from dominant political languages and institutions, such as the language of right. Since this doxa is also to be found amongst deep greens (to which I count myself), I revisit Lefebvre's critique and plea for a different political strategy: the active appropriation of political languages and institutions while changing the latter's underpinning grammar and "contracts of citizenship" (Lefebvre 2003a). In the following, I present his hetero-rights claims certainly not as a solution to socio-ecological impasses, but as a tool worth exploring and as a means to rattle at deeply engrained assumption in (some of the) current, bottom-up environmental practices and the discourses on them.

\section{Framing Political Claims as Right Claims: Or Why Marx and (Some Radical) Environmentalists May Be Mistaken in Their Dismissiveness of Dominant Political Languages and Institutions}

It may be puzzling that someone influenced by the Marxist tradition, as Lefebvre certainly was, rather affirmatively appropriates a discourse of rights. As is well known, Marx was a fierce critic of the idea of human rights, the role it played in bourgeois revolutions, and, relatedly, liberal political institutions. He argued that the rights of men are never universal but always particular rights: the

2 I am fully aware of and, of course, recognize that urban bottom-up environmentalism comes in many different forms, with many different normative outlooks, and drives (on the pluralism within alternative, local, gardening and farming practices, see, for instance, (Ernwein 2014; McClintock 2014; Yang and Carolin 2019) in this Special Issue.) This does, however, not have any effect on my critical perspective on the readiness with which some scholars (and also practitioners) attribute transformative thrust to them(selves) with view to handling socio-ecological challenges.

3 Efforts and commitments, we are observing in our own empirical research on bottom-up environmental initiatives in Vienna funded by the Austrian Science Fund (Project\#: P31226-G29). Our own empirical findings have, however, not yet been published. 
rights of bourgeois men (Marx 1844/1976). By being presented as the rights of men tout court, they not only mystify social inequalities but also actively entrench them. The right to private property, for instance, clearly privileges those who own more than their labor power due to the lottery of birth, that is, due to having been born into a rich rather than a poor family. As Anatole France once put it, "the majestic quality of the [liberal, my insertion] law [ ... ] prohibits the wealthy as well as the poor from sleeping under the bridges, from begging in the streets, and from stealing bread" (France 1894/2006). Marx was critical of the mystifying function of the liberal rights discourse, but also because of the latter's reduction of the meaning of freedom to the freedom "from others", that is, the freedom of non-interference. From a Marxian perspective, freedom is social and can only be understood socially. That is, fellow human beings are not conceived of as a barrier to but as a precondition for my own freedom. I can only be free because I, together with others, determine the meaning of freedom and provide for its economic, social, and political conditions of possibility.

Lefebvre was, of course, fully aware of these Marxist critiques of the liberal discourse of rights. Nevertheless, he took recourse to it in his writings on cities. More so, he suggested its appropriation for not only reforming but transforming the societal status quo (Lefebvre 2003a). In the liberal tradition, claiming rights usually means one of the following two things: extending an existing catalog of rights to a hitherto disenfranchised group (e.g., women's right to vote; religious or cultural rights for minorities; legalization of gay marriage) or expanding an existing set of rights by a new set of rights (e.g., social rights which were "added to" civil and political rights due to highly successful working-class mobilization. Lefebvre, however, was not interested in either. For him, formulating political claims in the language of rights served, among others, a strategic purpose. It is easier to mobilize a collective subject in the name of a right in late modern, liberal-capitalist societies, such as the right to the city, to public housing, to public transit, or to food sovereignty than in the name of a more abstract political goal, such as the end of capitalism. Yet, for a rights claim to be transformative instead of simply reformatory, it has to be formulated in such a way that it is, as Margaret Kohn puts it with view to Lefebvre, located "inside and outside of a dominant order" (Kohn 2016, p. 188; see also Lefebvre 1996b, 2003a).

To illustrate how right claims can be formulated as heterodox right claims, let's take a closer look at the example of the Right to the City: the specific form of the claims, the right form, is a common form of making claims in a liberal democratic context. Yet the object of the right's claim, the city, points beyond such a context. The city, given its contested meaning (see, among others, the discussion of radically different interpretations of the urban above), collective and diverse nature cannot be owned akin to how one owns "the body, the home, the castle" (Kohn 2016, p. 187). Although a person (be the latter natural or juridical) may acquire large parts of urban land and urban real estate, $\mathrm{s} / \mathrm{he}$ is nonetheless not in the possession of the city, since the latter exceeds what can be acquired, owned, or exchanged on a liberal capitalist market. The city encompasses not only private property (which can be exchanged on a market), but also public infrastructures (which are exempt from market relations); it is shaped and re-shaped by societal and planetary processes that exceed the sphere of influence of any given person (e.g., a water supply systems, electricity networks, the availability of labor); and it entails ways of life and social imaginaries that conflict with norms related to private ownership (e.g., social networks, communities, cultures, and subcultures). Thus, from a traditional liberal rights-perspective, claiming a right to the city is rather incomprehensible (Ibid., pp. 187-88). Yet this very incomprehensibility is an entry point for re-politicizing the very meaning of the city (can we still speak of "the city" in an urbanized society?) and existing structures of ownership in as well as questions of entitlement to the city (who is the subject of the right to the city?). Lefebvre's plea for claiming the right to the city was, as Kohn puts it, not conceived of "as a way of resolving conflicts over right but as a way of staging such conflicts" (Ibid., 187). He suggested speaking the key language of liberal politics, the language of the right, while seeking to transform the latter's grammar. In the words of Margaret Kohn:

“'Hetero-rights' [... ] expose the limits of dominant ways of thinking about political problems, but they $[\ldots]$ cannot be realized by gradually expanding rights. They are political tools 
[emphasis added], because they make claims about injustice that cannot be resolved without political change." (Ibid., p. 189)

The normative horizon towards which Lefebvre wanted to see the grammar shift was democratic socialism. Self-rule and participation (instead of statism); property relations that would prioritize the utility value of things, spaces, and social relations higher than their exchange value; and a redefinition of human freedom that would give ample space to the explorative and playful, i.e., to the ludic dimensions of human life, were key to Lefebvre (see Lefebvre 1996b, 2003b; but also Schmid 2005). The idea of framing political claims as hetero-rights is, however, not bound to Lefebvre's specific normative horizon, which one may find convincing or not. As this section seeks to emphasize, heterodox right claims may also serve as a relevant political tool and as a means to reflect critically on existing political strategies and doxa related to them in other political contexts, such as struggles for greater sustainability.

I consider there to be numerous reasons for heterodox rights to be of relevance for environmental interventions. Strategically, formulating environmental demands in the language of rights may increase the chances of being heard and perceived more widely. It may also open the door towards building coalitions between different social groups and across issues: the creation of "chains of equivalence" (Laclau and Mouffe 2001, p. 136). Thus, appropriating the language of rights in a heterodox way may help overcome the "resonance dilemma" (Meyer 2015) that niche interventions often face. Politically, environmental change hinges on politicizing and transforming the unsustainable processes and scripts that underpin urbanized everyday life, including living, consuming, working, and moving from A to B. In liberal societies, how people live, eat, consume, and get around is widely perceived as archetypically belonging to the private sphere. Although this is, of course, not an empirical truth, since housing, work-life, leisure, consumption, and mobility are heavily shaped by laws, regulations, and public infrastructures, these domains of everyday life are closely associated with individual freedom, including the freedom from interference by others and from the state (see also Meyer 2015). Thus, similar to the feminist politicization of family life, which was long perceived as archetypically belonging to the private sphere, politicizing (private) everyday life, including its societal and planetary implications, is certainly crucial to pursuits of more sustainable nature-society relations.

But politicization alone, is, from the Right to the City perspective, not enough. Claiming the Right to the City, when understood as a claim to a hetero-right, means formulating political claims in such a way that they, on the one hand, strike a responsive chord among different interest groups and seem to be realizable within a given social and political order (a strategy to circumvent, among others, outright opposition by the state) while, on the other hand, actively pursuing the transformation of an established order's fundaments. Let's take the example of claiming the right to public transport. This claim is a common one among environmentalists, given the adverse environmental effects of individual transport. It is also a common claim among social activists, such as housing and anti-gentrification activists, given the well-known negative correlation between housing affordability and public infrastructure, i.e., the decrease in the former as a result of an expansion or improvement of the latter. To be sure, a joint coalition between environmentalists and social activists fighting for a right to public transport may be reduced to a struggle for the mere expansion of existing public infrastructures. Yet formulating claims to a right to public transport as a hetero-right means more than asking for more trains and buses. If public transport is framed as a right every citizen and urban dweller is entitled to rather than an option or asset ${ }^{4}$ some people have access to while others do not, based on financial resources, this would, for one, imply a massive expansion of existing public infrastructures and, relatedly, the curtailment of private transport. It would also imply a fundamental rethinking of existing mobility concepts, land-use

4 Public transport becomes an asset if public investments allow for private capitalizations on them. An example of the latter are laws and regulations that permit private property holders to charge higher rents and property prices if the real estate object is well embedded in public infrastructure. 
practices, and private property arrangements through the lens of the public: Which mobility concepts and related infrastructures and settlement patterns are in the interest of the public against the backdrop of socio-ecological challenges? Who is to be served and why? What is the very meaning of the public with a view to mobility questions and questions of social-ecological challenges and in-justices?

As mentioned above, formulating demands in the language of rights while seeking to change the latter's grammar was not an option for Marx. The same applies to environmentalists who decide for other political languages, such as civil disobedience (a more radical political language than the language of hetero-rights) or sustainable consumerism (a less radical political language than the language of hetero-rights). All these different political strategies come with their own, respective benefits and risks. The main risk that comes with speaking the language of (hetero-)rights is the risk of co-option. Right claims have an addressee, most commonly, the (local) state: the grantor of rights. Even if heterodox right claims aim at transforming the state's fundament by asking not only for the adaptation of existing contracts of citizenship but for their transformation, the grantors of rights remain in a position of power: they may or may not listen to the claimant; they may give in to far-reaching demands or pull the teeth of the latter. Fully aware of the risk of co-option by employing the language of rights in pursuit of not only lifeworld but planetary environmentalism, I nonetheless take up the cudgels for a heterodox appropriation of the language of rights-especially in the context of environmentalism and against the backdrop of worsening socio-ecological conditions.

Law, to be sure, not only mystifies and excludes, but also enables. The same, one may argue, applies to the political institutions and the public infrastructures that shape our everyday lives and environs. Neither law, nor political institutions, nor public infrastructures merely subject us. Although they are depoliticizing in the sense that every institution, qua definitionem, builds on habitualization ${ }^{5}$, there is more to the law (the focus of Lefebvre), institutions, and public infrastructures (my added foci) than subjection and depoliticization. Law also connects us as citizens (see, among others, Bonnie Honig's 2011 exploration of public things that connect us as citizen 2011) and "public infrastructures" are, in many ways, the conditio sine qua non, the "foundational economy", for neo-capitalist modes of production. Both are subject to political making and re-making, e.g., among socio-ecological lines. One may seek to map, politicize, and transform unsustainable societal and planetary processes at a deliberate distance from law, institutions, and infrastructures, that is, from within a society's niches, cracks and at its margins. However, one may also actively engage with and re-appropriate law, political institutions, and public infrastructures in order to shift the latter's grammar and underlying "contracts of citizenship".

Without seeking to present heterodox right claims as "solutions" to current socio-ecological challenges, I do present them as a perspective that invites critical reflection on academic foci on environmental activism at society's margins and from within its niches and cracks and the readiness with which transformative thrust is ascribed to such activism. I also introduce heterodox rights-claims as another possible and so far (largely) underexplored way of pursuing radical, environmental change-underexplored also in conceptual framings of radical change. Lefebvre remarked, with a view to the Marxist tradition to which he was in many ways indebted, that its common out of hand rejection of the discourse of may have been a fallacy (Lefebvre 2003a). The point of this section is to repeat this critical remark with a view to environmental activists and scholars who bet their horses on the conviction that radical change is most likely to come from societal margins, cracks, and niches.

5 As Berger and Luckmann famously point out, institutionalization is the effect of habitualization that shapes horizons of expectations. Institutionalization, which they understand as the institutionalization of knowledge, facilitates modern life. It liberates us from having to constantly re-invent and re-decide what we do, how we act, and what we believe to be right as opposed to wrong. 


\section{Conclusions}

Historically speaking, as David Wachsmuth puts it, environmental sociology has had little to say about the urban except "to treat it as a machine [or, as I would add, site] for consuming nature" (Wachsmuth 2012). Similarly, it may be argued, environmental politics has had little to say about the urban except to conceive of it either as a territorially bound scale of governing-the local state (Betsill and Bulkeley 2007)—or as a "space of appearance" (Arendt) for civil-society driven forms of environmental action (Paech 2011; Meyer 2015; Schlosberg and Craven 2019). By bringing environmental sociology and politics into conversation with urban theory, this paper seeks most importantly to spark greater reflexivity on how the urban is framed in environmental discourses and interventions, that is, greater reflexivity on epistemologies of the urban. Depending on how the urban is understood and framed in given interventions and discourses, urban environmentalism may mean mere lifeworld environmentalism (the greening of local environs), but it may also mean planetary environmentalism (the problematization and transformation of processes that become manifest in a given space, but that also transcend the latter). Thus, against the backdrop of the theory of the urban that underpins Lefebvre's Right to the City, this paper has argued that the scope of and limits to the transformative thrust of urban environmental interventions and citizenship hinges not only on the nature of the practices and the normative goals pursued but also on how the urban is understood and framed.

The paper has excavated the theory of the urban that underpins Lefebvre's writings as potentially relevant for urban environmental sociology and politics. It has also unearthed the specific political strategy that underlies the Right to the City-idea as potentially relevant for rethinking environmental strategies and doxa among (some) environmental scholars (and activists): the doxa that radicalism is to be most commonly found in society's niches, margins, and cracks. Recognizing that even active pursuits of planetary, that is, more radical, environmentalism seem to often remain stuck in lifeworld reform, this paper foregrounds heterodox right claims as a political strategy worth exploring for environmental purposes. Formulating radical political demands as heterodox right claims means, as was explained, appropriating dominant political languages and institutions, such as the language and institution of law, while changing the latter's grammar and "contracts of citizenship" towards, e.g., grammars that foreground socio-ecological justice and redefine existing compacts of citizenship along socio-ecological lines. In short, the paper has also argued that ecological citizenship may be re-invigorated not only from within society's cracks, niches, and margins but also by appropriations and (creative and cunning) reconfigurations of dominant political languages and institutions-a form of reinvigoration current academic debates on bottom-up environmentalism seem to be paying little attention to.

Funding: This research was funded by the FWF Austrian Science Fund, grant number P31226-G29.

Conflicts of Interest: The author declares no conflict of interest.

\section{References}

Angelo, Hillary. 2017. From the City Lens Toward Urbanisation as a Way of Seeing: Country/city Binaries on an Urbanising Planet. Urban Studies 54: 158-78. [CrossRef]

Angelo, Hillary, and David Wachsmuth. 2015. Urbanizing Urban Political Ecology: A Critique of Methodological Cityism. International Journal of Urban and Regional Research 39: 16-27. [CrossRef]

Baker, Susan. 2007. Sustainable Development as Symbolic Commitment: Declaratory Politics and the Seductive Appeal of Ecological Modernization in the European Union. Environmental Politics 16: 297-317. [CrossRef]

Barry, John. 2003. Ecological Modernisation. In Environmental Thought. Current Issues in Ecological Economics. Edited by Edward A. Page and John Proops. Cheltenham: Edward Elgar Publishing, pp. 191-213.

Bendell, Jeremy. 2018. Deep Adaptation: A Map for Navigating Climate Tragedy: IFLAS Occasional Paper 2. Unpublished Manuscript, last modified 9 January 2020. Available online: www.iflas.info (accessed on 3 November 2019). 
Betsill, Michele, and Harriet Bulkeley. 2007. Looking Back and Thinking Ahead: A Decade of Cities and Climate Research. Local Environment 12: 447-56. [CrossRef]

Blühdorn, Ingolfur, Felix Butzlaff, Michael Deflorian, Daniel Hausknost, and Mirijam Mock. 2019. Nachhaltige Nicht-Nachhaltigkeit: Warum die ökologische Transformation der Gesellschaft nicht stattfindet. Bielefeld: Transcript.

Boltanski, Luc, and Arnaud Esquerre. 2020. Enrichment: A Critique of Commodities. Cambridge and Medford: Polity Press.

Brand, Ulrich. 2010. Sustainable Development and Ecological Modernization-The Limits to a Hegemonic Policy Knowledge. Innovation -The European Journal of Social Science Research 23: 135-52. [CrossRef]

Brand, Ulrich, and Markus Wissen. 2018. The Limits to Capitalist Nature: Theorizing and Overcoming the Imperial Mode of Living. Transforming Capitalism. London: Rowman \& Littlefield International.

Brenner, Neil, ed. 2017. Implosions-Explosions: Towards a Study of Planetary Urbanization, 2nd ed. Berlin: Jovis.

Brenner, Neil, and Christian Schmid. 2011. Planetary Urbanization. In Urban Constellations. Edited by Matthew Gandy. Berlin: Jovis-Verl, pp. s10-14.

Brenner, Neil, and Christian Schmid. 2014. The 'Urban Age' in Question. International Journal of Urban and Regional Research 38: 731-55. [CrossRef]

Brenner, Neil, and Christian Schmid. 2015. Towards a New Epistemology of the Urban? City 19: 151-82. [CrossRef]

Bulkeley, Harriet, Vanesa Castan Broto, Mike Hodson, and Simon Marvin, eds. 2010. Cities and Low Carbon Transitions. London: Routledge.

Bulkeley, Harriet, Vanesa Castán Broto, and Gareth Edwards. 2014. An Urban Politics of Climate Change: Experimentation and the Governing of Socio-Technical Transitions. Hoboken: Taylor and Francis, Available online: http://gbv.eblib.com/patron/FullRecord.aspx?p=1818201 (accessed on 30 October 2019).

Ernstson, Henrik, and E. Swyngedouw, eds. 2019. Urban Political Ecology in the Anthropo-Obscene: Interruptions and Possibilities. Questioning Cities. Abingdon and New York: Routledge.

Ernwein, Marion. 2014. Framing Urban Gardening and Agriculture: On Space, Scale and the Public. Geoforum 56: 77-86. [CrossRef]

Fladvad, Benno. 2019. Diverse Citizenship? Food Sovereignty and the Power of Acting Otherwise. Social Sciences 8: 331. [CrossRef]

Fritz, Martin, and Max Koch. 2016. Economic Development and Prosperity Patterns Around the World: Structural Challenges for a Global Steady-State Economy. Global Environmental Change 38: 41-48. [CrossRef]

Global Covenant of Mayors for Climate and Energy. 2019. Available online: https://www.globalcovenantofmayors. org/ (accessed on 29 December 2019).

Hajer, Marteen, and Ton Dassen. 2014. Smart About Cities: Visualizing the Challenge for 21st Century Urbanism. Rotterdam: Nai010 Publishers.

Hausknost, Daniel. 2019. The Environmental State and the Glass Ceiling of Transformation. Environmental Politics 29: 17-37. [CrossRef]

Kohn, Margaret. 2016. The Death and Life of the Urban Commonwealth. New York: Oxford University Press.

Laclau, Ernesto, and Chantal Mouffe. 2001. Hegemony and Socialist Strategy. Towards a Radical Democratic Politics, 2nd ed. London: Verso.

Lawhon, Mary, and Zarina Patel. 2013. Scalar Politics and Local Sustainability: Rethinking Governance and Justice in an Era of Political and Environmental Change. Environment Planning C Government Policy 31: 1048-62. [CrossRef]

Lefebvre, Henri. 1991. The Production of Space. Oxford: Blackwell.

Lefebvre, Henri. 1996a. The Right to the City. In Writings on Cities. Edited by Eleonore Kofman and Elizabeth Lebas. Oxford: Blackwell, pp. 63-181.

Lefebvre, Henri. 1996b. Writings on Cities. Edited by Eleonore Kofman and Elizabeth Lebas. Malden and Oxford: Blackwell Publishing.

Lefebvre, Henri. 2003a. From the Social Pact to the Contract of Citizenship. In Henri Lefebvre. Key Writings. Edited by Stuart Elden, Elizabeth Lebas and Eleonore Kofman. New York: Continuum, pp. 238-54.

Lefebvre, Henri. 2003b. The Urban Revolution. Minneapolis: University of Minnesota Press.

Lefebvre, Henri. 2009. State, Space, World. Selected Essays. Edited by Neil Brenner and Stuart Elden. Minneapolis: University of Minnesota.

Lessenich, Stephan. 2019. Living Well at Others' Expense: The Hidden Costs of Western Prosperity. Medford: Polity. 
MacGregor, Sherilyn. 2019. Finding Transformative Potential in the Cracks? The Ambiguities of Urban Environmental Activism in a Neoliberal City. Social Movement Studies 16: 1-17. [CrossRef]

McClintock, Nathan. 2014. Radical, Reformist, and Garden-Variety Neoliberal: Coming to Terms with Urban Agriculture's Contradictions. Local Environment 19: 147-71. [CrossRef]

McKibben, Bill. 2006. The End of Nature, Random House Trade Paperback ed.; New York: Random House Trade Paperbacks. Available online: http://www.loc.gov/catdir/enhancements/fy0704/2006283925-b.html (accessed on 25 October 2019).

Merrifield, Andy. 2013. The Urban Question Under Planetary Urbanization. International Journal of Urban and Regional Research 37: 909-22. [CrossRef]

Meyer, John. 2015. Engagig the Everday. Environmental Social Criticism and the Resonance Dilemma. Cambridge: MIT Press.

Mitchell, Timothy. 2013. Carbon Democracy: Political Power in the Age of Oil. London and New York: Verso.

Muraca, Barbara. 2017. Against the Insanity of Growth: Degrowth as Concrete Utopia. In Socialism in Process. Edited by Justin Heinzekehr and Philip Clayton. Toward Ecological Civilization Series. Anoka: Process Century Press, pp. 147-69.

Paech, Niko. 2011. Befreiung Vom Überfluß. Auf Den Weg in Die Postwachstumsökonomie. München: Oekom Verlag. Pellizzoni, Luigi. 2020. The Environmental State Between Pre-Emption and Inoperosity. Environmental Politics 29: 76-95. [CrossRef]

Schlosberg, David. 2019. From Postmaterialism to Sustainable Materialism: The Environmental Politics of Practice-Based Movements. Environmental Politics 8: 1-21. [CrossRef]

Schlosberg, David, and Luke Craven. 2019. Sustainable Materialism: Environmental Movements and the Politics of Everyday Life, 1st ed. Oxford: Oxford University Press.

Schmid, Christian. 2005. Stadt, Raum Und Gesellschaft. Stuttgart: Franz Steiner Verlag.

Schneidewind, Uwe. 2018. Die Große Transformation: Eine Einführung in Die Kunst Gesellschaftlichen Wandels. Frankfurt am Main: Fischer Taschenbuch.

Soper, Kate. 2016. Towards a Sustainable Flourishing. Ethical Consumption and Politics of Prosperity. In Ethics and Morality in Consumption. Edited by Deirdre Shaw, Andreas Chatzidakis and Michal Carrington. Abingdon: Routledge, pp. 11-27.

Steffen, Will, Wendy Broadgate, Lisa Deutsch, Owen Gaffney, and Cornelia Ludwig. 2015. The Trajectory of the Anthropocene: The Great Acceleration. The Anthropocene Review 2: 81-98. [CrossRef]

Stolle, Dietlind, and Michele Micheletti. 2015. Political Consumerism: Global Responsibility in Action. New York: Cambridge University Press.

UN-Division for Sustainable Development Goals. 2019. Sustainable Development Goals (SDG). Available online: https://sustainabledevelopment.un.org/sdg11 (accessed on 19 November 2019).

UN-Habitat-United Nations Human Settlements Programme. 2011. Global Report on Human Settlements 2011: Cities and Climate Change. Abingdon: Routledge.

Wachsmuth, David. 2012. Three Ecologies: Urban Metabolism and the Society-Nature Opposition. The Sociological Quarterly 53: 506-23. [CrossRef]

Wachsmuth, David. 2014. City as Ideology: Reconciling the Explosion of the City Form with the Tenacity of the City Concept. Environ Plan D 32: 75-90. [CrossRef]

Wachsmuth, David, and Hillary Angelo. 2018. Green and Gray: New Ideologies of Nature in Urban Sustainability Policy. Annals of the American Association of Geographers 108: 1038-56. [CrossRef]

WBGU. 2016. Humanity on the Move: Unlocking the Transformative Power of Cities. Berlin: WBGU.

Yang, Mundo, and Zorell Carolin. 2019. Real World Citizenship Between Political Consumerism and Material Practices. Social Sciences 8: 311. [CrossRef]

(C) 2020 by the author. Licensee MDPI, Basel, Switzerland. This article is an open access article distributed under the terms and conditions of the Creative Commons Attribution (CC BY) license (http://creativecommons.org/licenses/by/4.0/). 